\title{
Reclaiming Identity
}

I have been on an ongoing journey of self-discovery. I grew up knowing my maternal grandfather's indigenous Cook Island Māori heritage, however I knew little of my Māori whakapapa or biological father's Cook Island Māori heritage. As a result, I undertook this journey to find out 'who I am' and how I belong in the world. This article I will describe key experiences and people that have impacted my life, and explain how these experiences have influenced my interest in my identity. Having experienced this journey to reclaim my identity, I now realize my mana. Therefore, I acknowledge and celebrate my identity. My identity is taonga, and as a Māori and Cook Island Māori man I believe I am privileged with my birth right. My indigenous practice is the promotion of Māori and indigenous identity for the positive development of Māori and indigenous youth. In this essay, I will argue that having a strong sense of identity strengthens an individual's mana and the mana of the individual's family.

My maternal grandfather, William Cuthers, had a strong sense of his own mana as a Cook Island Māori, mana which was passed down to him. William was born and raised in Rarotonga and was whāngai from birth by Kiriakama, his father's eldest brother, the mātāmua of the Cuthers family. Mead (2003) says, "a child's inheritance of mana depends upon the achievements of the parents, their social position, how they are regarded by others and what they have done to assist the tribal group" (p. 56). Kiriakama had served in World War II, and he was a police officer in the village of Titikaveka. He also carried out his duties 
for the family in relation to the kaitiakitanga of ancestral land. These roles complimented his seniority within the family and contributed to his mana. As William was regarded by the family as the mātāmua of Kiriakama, he received Kiriakama's mana.

My grandfather returned to Aotearoa with the Polynesian diaspora of the 1950s. I say returned because William was also Māori of Aotearoa, through his birth mother, Tutevera, who was of Ngāti Tamainupō descent. In Aotearoa William married a Pākehā woman named Jean in 1953. Together they had six children, the third child of which is my mother, Rauru'ina. Translated from Cook Island Māori, Rauru'ina means "grey hair". This was the name of the woman who raised William with Kiriakama. Jonassen (2003) explains that names play an important role in the traditional life of Māori, and names maintain interconnections to ancestors, family and land. Naming is important to the maintenance of identity. My mother's name is significant because it connects her to our heritage. The name Rauru'ina speaks of who my mother is and keeps alive the belief that the spirit of the dead never leaves us (Jonassen, 2003).

My tupuna, Rauru'ina, is always with us, because we keep her name with us. We acknowledge her and continue to make her significant. In doing so, we acknowledge our own mana because our tupuna are part of us, part of our history. When my daughter was born, I "put Rauru'ina on her names", as Cook Island Māori say; I gave her mana tupuna. It was not something my mother or grandfather asked of me. However, Wendt says "we are what we remember" (Sharrad, 2013, p. 211). I remembered the significance of Rauru'ina. Furthermore, my mother named me after her father. I carry his name, a name that I am very proud of. My name symbolizes him, and represents our family and who we are. My grandfather is still here because we all speak his name, even though he has long passed. Remembering him allows me to connect to him today, and in doing so my grandfather is still teaching me. 
My grandfather William was one of my earliest teachers who taught me through stories of his heritage. According to Cain, Kahu, and Shaw (2017), our narratives carry instruction from our tupuna about proper conduct and behavior. Our stories are our history and are an important component of our identity that should be treated as taonga. Smith (1999) says, "the story and the story teller both serve to connect the past with the future, one generation with the other" (p.146). My grandfather would sit on his chair and tell me about his grandmother, Koi, who was a Queen on the island of Mangaia. He would say, "she was big, black and ugly, with juju lips and had all the men chasing after her". Gregory (2009) says that stories allow us to connect emotionally. I laugh about that story, even now, as I recall the way he told it. His stories enabled me to locate myself within the narrative, connecting me with Koi and my other tupuna through time.

Koi was born in Mangaia. She descended from Vatea, the sky father, and Papa'uenuku, the earth mother, through their son, Tāne Mā'uta. Koi was also known as Piapaina and she was the mātāmua of the Ngāti Tāne chief Vaipo Tokoua. The name they use to describe women of high rank or the eldest daughter of a chief is 'tapairu'. Koi was 'tapairu' (Chadwick \& Chadwick, 1968). It explains what my grandfather was told about her and why she was depicted as being a Queen. Whakapapa and tupuna are central to identity, and provide a sense of place (Rocha \& Webber, 2018). Stories such as hers enabled a sense of identity; I became part of the stories and I felt mana tupuna. I retell this particular story to my children, just as my grandfather told me. My children laugh when I describe Koi and ask why I tell the story the way I do. I respond that it was how my grandfather taught me and in doing so I connect one generation with another and maintain our mana tupuna.

Narratives are hugely important for developing a sense of identity and belonging (Cain et al., 2017). Listening to stories that explained my belonging contributed to how I saw myself and it developed my strong sense of mana. My grandfather 
gifted me a sense of identity early on in my life, through the stories he would tell. This was knowledge of self, passed from generation to generation through the use of stories. I now gift my children the same stories in order to give them a sense of belonging and to maintain our story. Smith (1999) agrees, "stories are ways of passing down the beliefs and values of a culture in the hope that the new generation will treasure them and pass the story down further" (p. 146). I understand the importance of our stories to transfer cultural knowledge and maintain identity and to teach.

Stories were hugely important in maintaining our culture within my mother's family, especially given that my grandfather did not teach his Cook Island Māori language to his children. According to my uncle, New Zealand was a Pākehā-dominated society and there were many prejudices against anyone who was not Pākehā in the 1950s (D. Cuthers, personal communication, March 22, 2018). My grandfather wanted his children to be able to make their way in New Zealand, and society influenced the way in which he raised his children. My grandfather demonstrated kaitiakitanga over his children's futures, because he protected them in the best way he could.

Nearing the end of his life, my grandfather wanted to go back to his place of birth. My uncle believes that his father knew he was on borrowed time when he returned to Rarotonga to build our home, but he wanted us, his descendants, to forge a bond with Rarotonga (D. Cuthers, personal communication, March 22, 2018). My grandfather built his house on his mother's land in the village of Arorangi, in the district of Puaikura. Through his mother, Tutevera, my grandfather was a mokopuna of the Paramount Ariki of Puaikura, Tinomana Enuarurutini. It was on Tinomana's land that he built his house. My grandfather died once his house was completed, and he was buried next to his house. Mead (2003) identifies that "Māori see themselves as not only of the land, but as the land" (p. 299). Cook Island Maori share this belief and our family continues to make the journey to my grandfather, our whenua. 
Therefore, he achieved the bond with his whenua that he wanted for us, his family. His grave on our whenua is a symbol of our identity. When we go to Rarotonga, we see that there he lies in perpetuity; the chief, the family and the land all in one. I feel a strong sense of mana because we are forever interwoven with the rich heritage of Puaikura through my grandfather.

Another of my early teachers was my stepfather, Kelekolio Tovia. He contributed to my understanding of identity by emphasizing the interconnectedness of chief, family and land. Kelekolio arrived from Samoa in the 1980s with another Polynesian diaspora. He began a relationship with my mother when I was 4 years old. Kelekolio was very proud of his identity as a Samoan, and his mana had a great influence on me. Nichol (2011) identifies that within indigenous societies learning occurs in informal, unstructured situations through observations. I learnt much about mana by observing the way Kelekolio practiced his culture. Kelekolio also utilized stories to teach me, because he believed that through stories I would learn the appropriate behavior and conduct for life. Shaw, Kelley, and Semler (2013) agree that storytelling is a method of persuasion.

Kelekolio's stories always had a purpose; they demonstrated what was right, and what was wrong. They also demonstrated how, by doing wrong, I could diminish my mana and the mana of my family and my tupuna. Through stories I was taught that identity was the result of understanding the interconnections of chief, family and land. According to Pratt and Harrison (2015), matai are heads of aiga and the matai title is strongly tied to family lands. Aiga, matai and land are synonymous and make up the identity of a member of the aiga. This collective mana is a foundation that an individual of the aiga inherits, which they can add to through their own achievements. Kelekolio taught me that identity was something situated between your heart and your lung, something that no one can ever remove.

According to Kelekolio, chief, family and land functioning as one equaled my identity or, in his words, my prestige, my mana. Explaining this model of understanding in a Māori context, it is 
understanding the relationship of my rangatira, my whanau and my whenua to each other, which contributes to my mana and my identity. Tomlins-Janke and Mulholland (2011) explain that kaitiakitanga binds the relationship between hapu and ancestral lands. When they work together as one their result is a collective mana that is also my mana, because I belong to the collective. Furthermore, in understanding myself I can understand how to positively interact with the world. Kelekolio's teachings encouraged me to seek out my biological father's heritage.

My father was Kainana Anguna, born in the village of Tupapa, Rarotonga. The relationship between him and my mother did not last. He became mentally ill and was diagnosed with schizophrenia. He moved home to Rarotonga, to his family, and our relationship was not the best. Not knowing my father played a large part in not understanding myself. He died in 2013, and I was informed after he had been buried. I did not know how to respond; I had many unanswered questions about who I was because of him. I had not told him I was married or that I had two children, and when he died I felt immense guilt about this. I was later contacted by a family member who told me that I needed to go to Rarotonga and mono him. The meaning of mono is 'to take the place of'; mono my father means to take over as kaitiakitanga of his land and his family. This, again, demonstrates the similarities between Te Ao Māori and Cook Island Māori and reiterates what Mead (2003) says about Māori being the land.

Time passed and I started to see my father in my dreams. He was not angry, he was just there. I kept this to myself until it began to burden me, so I told my wife. Barnett, Robinson, and Rose (2008) say that ghosts evoke intense feelings such as guilt and inconsolable sorrow. My wife suggested that I go to Rarotonga to reconnect with my father. So in January 2014 my family and I made the journey to Rarotonga. We stayed at my maternal grandfather's home in Arorangi. On the first day of our arrival my son, my mātāmua, and I ventured to Tupapa. Mead 
(2003) states that first-borns have more mana than other siblings since they are given more opportunities to assume leadership roles. I take him with me so he can observe what I do, in order to learn what he needs to know and enhance his mana since he is kaitiakitanga over his younger siblings. This is an example of indigenous methods of teaching.

I did not know where my father was buried so I drove until I saw a headstone with the name Anguna on it. This one particular headstone faced the road, as if it were a marker to show me. This was it. I stopped the vehicle and read the headstone and identified that it was my great grandfather's headstone. His wife Poro'i, my great grandmother, was buried next to him. Deep inside I knew that this was where my father was buried. This is an example of tacit knowledge, because I felt inside my heart that he was close, and I was home. I looked around and saw a lone grave on the other side of a hedge. I knew this was his grave. I walked over towards it and tears streamed down my face.

I saw his headstone and his photo. His face was so familiar to me, even though we rarely saw each other in life. When I looked at him, I saw myself. I knelt forward and hugged his headstone and told him I was sorry. I introduced my son to his grandfather and told my father we had come home. I looked up at Ikurangi, the mountain that stared down at me, as I stood by my father's grave. There were clouds right up the top, as if the mountain disappeared among them. There were white birds flying around the clouds. I turned the other way and faced the ocean to see the waves crashing up against the coral reef. It was all beautiful. It was the first time I had been here and walked on the soil, however it was not new to me. I always 'knew' it existed. It always had meaning to who I was yet I had not seen it until this moment. This 'knowing' and this feeling of belonging are examples of tacit knowledge. Although I was emotional, I felt a strong sense of mana whenua.

The restoration of my own identity enabled me to further strengthen the mana of my children by letting them know who 
I was because of my father. I talked to a number of relatives who were able to explain more about my father to me and helped fill in gaps in my understanding. My father's cousin, Kopurei, helped me with my mono application. She also took the time to show me where all our family's lands were. According to Durie (2003), a secure identity depends on access to language, the extended family network and customary land. I was reconnecting and, through this process, I was healing. My father belonged to land extending from the coral reef right up into the mountains. The land where my father is buried, Punataia, is one of his family's lands. The mountain Ikurangi is part of Punataia; we belonged to that mountain that stared down at me when I first saw my father's grave. Kopurei explained that through Anguna we descend from the mata'iapo Vakāpora, and through Poro'i we descend from the rangatira Pā Puia and Paetaro of the island of Atiu. Anguna and Poro'i were prominent people in their time and, as result, our family was too. Mana tupuna is the authority that comes from one's whakapapa and is passed from one's tupuna (Jones, 2016). I began to understand that my father wanted me to return to Rarotonga to know my mana.

My great grandmother Poro'i was a ta'unga or, as my cousin Anguna describes her, a 'witch doctor'. She saw the spirits of the dead, she foresaw who would die; she also knew about herbal medicines. (A. Anguna, personal communication, May 11, 2018). I told Kopurei that I had seen my father and I asked her what else he wanted me to know. Ghosts can help us to recognize that something remains unresolved (Barnett, Robinson \& Rose, 2008). However, this was not the first time I had seen the dead; my maternal grandmother appeared to me after she had died. This ability, to see the spirits, was knowledge I had acquired seemingly from Poro'i and, according to my father's family, from my father and his mother. I asked my cousin how it is that we can acquire knowledge from tupuna we never met. Anguna explained that the elders know the actions of the past because they saw them and if they see a descendant 
doing the same, then they know the ancestors "passed their knowledge onto you" (A. Anguna, personal communication, May $11,2018)$. This is intergenerational transfer of tacit knowledge.

Kopurei took me to the frame of a very old coral house. She told me that my father was whāngai by his father's elder brother, also named Kainana, and raised at this coral house. This was where I belonged. She told me that I was part of the coral, built into the structure (K. Anguna, personal communication, March 19, 2018). She was teaching me about my connection to place and telling me the story of my father that I did not know. Her story connected me to Kainana. I saw his grave at the front of his house. Even though he had died well before I was born, I felt a strong emotional connection with him and his house and his land. I knew him. This is another example of tacit knowledge.

Once I knew and understood my connections to family and land I was able to teach my children more about who they were. I returned to Rarotonga with my two eldest children to mono my father. My children accompanied me because I wanted them to understand what I was doing, so they would know to do the same in the future when I die; to mono me. I stood in the dock and the magistrate asked if I was the son of Kainana Anguna. I answered, "Yes". It was the first moment in my life that I acknowledged that he was my father. I then stood in the court for land occupation rights to the block of land where Kainana's coral house was. The justice of the peace said to me, "Your family is a good family, a well-known family here in Rarotonga". Mead (2003) says "people with mana are well placed in terms of whakapapa and come from chiefly lines or from important families" (p. 34). However, I believe that mana is not limited to people from chiefly lines and important families, it can be created by one's achievements.

After the mono I took my children and showed them the land that we belong to. I explained that I was kaitiakitanga over the land now, and they would be kaitiakitanga over the land in the future. I was teaching them who they were because of me and 
the responsibilities that they would inherit. I explained how our whakapapa tied us to chief and family. I used narratives of the history of each land, with some stories dating back to Tangi'ia and the Takitumu Vaka arrival in Rarotonga. I demonstrated how significant we are because of our whakapapa which was an unbroken chain that we connect to. According to Leahy (2015), whakapapa is an enduring legacy that gives us our place in the world. My paternal grandmother Tevairangi Enoka was whāngai by her mother's brother, Ringiao Manārangi, who was Potikitaua, the high priest of Arai te tonga. Her biological father, Tuainekore Enoka, descended from the rangatira Anautoa and her mother Akatoka Manārangi was the mata'iapo Uirangi of Arai Te Tonga. Understanding my father through my model of understanding enabled me to strengthen my identity and restore mana in myself.

In finding out about my father, I continued my journey to find out about my Māori whakapapa resulting in the identification of my hapū, Ngāti Tamainupō, and iwi, Tainui. I reconnected with my Māori whakapapa and achieved a strong sense of mana in being Māori. This resulted in my enrolment in He Waka Hiringa at Te Wānanga o Aotearoa to further acknowledge my identity.

My name is William Kainana Anguna, I am the only child of Kainana Anguna and Rauru'ina Cuthers. Through my father I am Ngāti Vakāpora and Ngāti Pā Puia. I am Ngāti Anautoa and Ngāti Uirangi. I am Ngāti Paetaro of Atiu. Arai Te Tonga is my marae. Through my mother I am Ngāti Tāne of Mangaia. I am Ngāti Tinomana of Puaikura, Rarotonga. I am Ngāti Tamainupō, I am the Waikato River, and I am the Taupiri Mountain. Te Papa O Rotu is my marae. My birth right as a Māori and indigenous man is to inherit the mana of this legacy. Mead (2003) says that people with mana draw their prestige from their ancestors.

In conclusion, having a strong sense of identity strengthens an individual's mana and the mana of the individual's family. A sense of identity is strengthened by identifying and maintaining connections to our ancestors through naming our children and 
sharing our stories. These forms of indigenous teaching enable a strong sense of belonging and allow connections across generations. Similarly, tacit knowledge is transferred through generations from our tupuna. We, the whānau, are the whenua and our whenua is part of our identity, from which we draw mana whenua. Chief, family and land are interconnected and together help to develop a secure identity. Furthermore, whakapapa allows an individual to locate themself in the world. Understanding identity enables an individual to enhance pride in themself and in their family, which contributes to positive development and well-being. 


\section{Bibliography}

Barnett, C., Robinson. \& Rose, G. (2008). Geographies of globalisation: A demanding world. Milton Keynes, United Kingdom: The Open University.

Cain, T., Kahu, E., \& Shaw, R. (2017). Türangawaewae: Identity and belonging in Aotearoa New Zealand. Auckland, New Zealand: Massey University Press.

Chadwick. H. M., \& Chadwick, N. K. (1948). The growth of literature. London, England: Cambridge University Press.

Durie, M. (2003). Ngā kāhui pou: Launching Māori futures. Wellington, Aotearoa New Zealand: Huia Publishers.

Gregory, M. (2009). Shaped by stories: The ethical power of narratives. Indiana, IN: University of Notre Dame Press.

Jonassen, J. (2003). Cook Island Māori names ingoa. Suva, Fiji: Institute of Pacific Studies, The University of the South Pacific.

Jones, C. (2016). New Treaty new tradition: Reconciling New Zealand and Māori law. Wellington, New Zealand: Victoria University Press.

Leahy, H. (2015). Crossing the floor: The story of Tariana Turia. Wellington, Aotearoa New Zealand: Huia Publishers.

Mead, H. M. (2003). Tikanga Māori: Living by Māori values. Wellington, Aotearoa New Zealand: Huia Publishers.

Nichol, R. (2011). Growing up indigenous: Developing effective pedagogy for education and development. Rotterdam, The Netherlands: Sense Publishers.

Pratt, S., \& Harrison, D. (2015). Tourism in Pacific Islands: Current issues and future challenges. Oxfordshire, England: Routledge.

Rocha, Z. L., \& Webber, M. (2018). Mana Tangatarua: Mixed heritages, ethnic identity and biculturalism in Aotearoa/New Zealand. Abingdon, England: Routledge.

Sharrad, P. (2003). Albert Wendt and Pacific literature: Circling the void. Manchester, United Kingdom: Manchester University Press.

Shaw, J., Kelley., \& Semler, L.E. (2013). Storytelling: Critical and creative approaches. England, United Kingdom: Palgrave Macmillan.

Smith, L.T. (2012). Decolonizing methodologies: Research and indigenous peoples (2nd ed.). Dunedin, New Zealand: Otago University Press.

Tomlins-Janke, H., \& Mulholland, M. (2011). Mana tangata: Politics of empowerment. Wellington, Aotearoa New Zealand: Huia Publishers. 